\title{
Style in Literary Translation: A Practical Perspective
}

\begin{tabular}{c}
\hline Ali Almanna \\
\hline Assistant Professor \\
Department of Foreign Languages \\
College of Arts and Sciences \\
The University of Nizwa \\
The Sultanate of Oman \\
a_abid12@yahoo.co.uk.
\end{tabular}

\begin{tabular}{c}
\hline Mohammed Farghal \\
\hline Professor \\
Department of English \\
College of Arts \\
Kuwait University \\
m_farghal@hotmail.com
\end{tabular}

Mohammed Farghal 


\title{
Style in literary translation: A practical perspective
}

\author{
Ali Almanna and Mohammed Farghal
}

\begin{abstract}
This paper explores a stylistic approach to translating literary texts from Arabic into English and vice versa. It is held that in order to be in a position to render literary texts effectively and accurately, one needs to: (1) analyze and describe varieties of language, (2) identify and discern all important aesthetic aspects of text in order to interpret and appreciate texts properly, (3) activate processes and experiences of reading along with one's intuitive responses to the text, and (4) activate all aspects of knowledge stored in one's mind on language, text-typological demands, generic conventions, sociological roles of participants in the real world and in text, cultural environment and so on. Through the analysis of authentic data, it argues that by adopting a comprehensive stylistic approach, translators, as special text readers, can easily derive a better understanding and appreciation of texts, in particular literary texts. The data analysis demonstrates that literary translators, in addition to possessing other types of competences, need to develop first an analytical and evaluating competence that enables them to analyze and appreciate stylistic features, and second transferring/translating competence that enables them to prioritize the competing elements with a minimum loss.
\end{abstract}

Keywords: style, translation, stylistic features, cognitive stylistics, linguistic stylistics, literary stylistics.

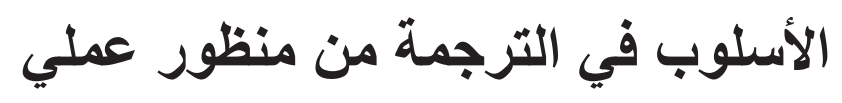

$$
\text { علي المناع ومحمد علي فرغل }
$$

مستخلص

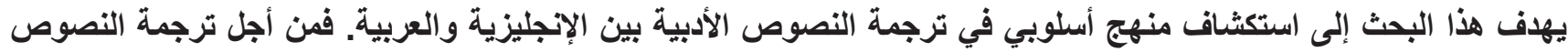

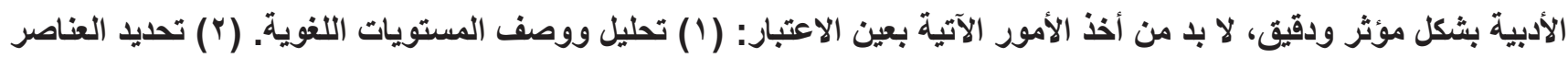

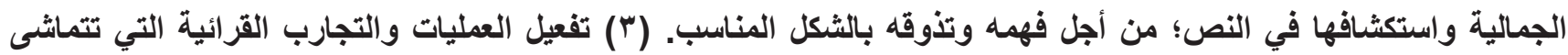

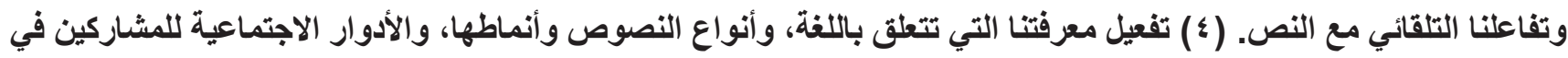

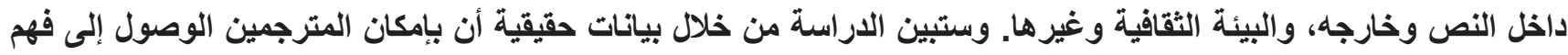

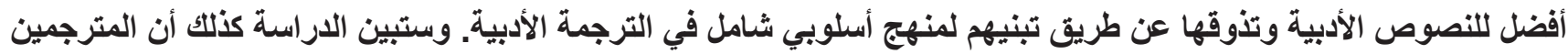

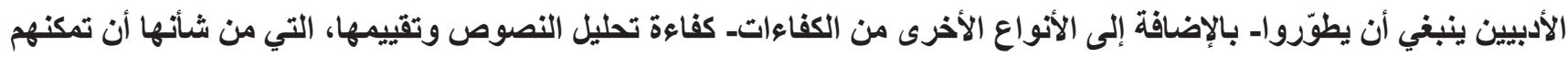

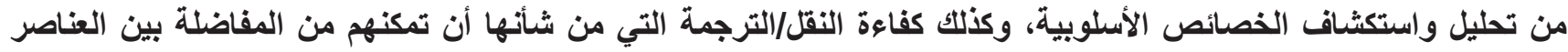
المتنافسة؛ بغية اختيار الأصلح واستبعاد الأخرى؛ من أجل تقليل جحم الخسائر أثناء عملية الترجمة.

كلمات مفتاحية: الأسلوب، الترجمة، الخصائص الأسلوبية، الأسلوبية الإدراكية، الأسلوبية اللفوية، الأسلوبية الأدبية. 


\section{Introduction}

Many attempts in the field of Translation Studies have been made to touch on the style for some time now (see for example Nida 1964; Lotman 1970; Venuti 2000; Zyngier 2001; Ghazala 1996, 2011; Bassnett 2002; Huang 2011; Makokha et al 2012; Almanna 2013). However, formulating a rigorous definition of what style exactly is remains ambiguous in nature, and the investigation is still unsystematic. In this regard, Boase-Beier (2006: 1) comments: "From the earliest writings about translation, such as those of Cicero or Horace, style has often been mentioned but [...] its role has rarely been systematically explored. Yet style is central to the way we construct and interpret texts". Snell-Hornby (1995: 119) holds that any attempt to discuss style will be considered unsatisfactory, since first "no coherent theoretical approach is attempted" and second "the problem of style recedes perceptibly into the background". The term style is applied to various spheres of human activities, such as: an individual (people have their own different styles), a distinct personality (the style of Dickens), a period (the Victorian style), an individual tone used while communicating to one another, a mode of tradition (to live in style), etc. Style (derived from the Latin word stylus meaning stake or pointed instrument for writing), obviously, is the object of study for stylistics. But what does stylistics mean? In order to be in a position to define stylistics, one needs to define style first as any definition of one concept would depend on a definition of another. Building on an assumption that within any language system (phonetics, graphology, semantics, grammar (morphology and syntax) and pragmatics), the same proposition can be encoded in various linguistic forms, i.e. styles, one can derive a better understanding of style. To put this differently, the same idea can be communicated in more than one way, thereby presenting a variability at the level of, let us say, intonation, type of writing, word and/ or expression choice, morphological and syntactic organization, and illocutionary force of an utterance. Style is defined by Leech and Short (1981: 10-11) as "the linguistic habits of a particular writer [...], genre, period, school". Style is seen by other stylisticians as "the dress of thought" (Hough 1969: 3). Formalists, however, define style as "a deviation from language norms. It is also claimed to be an expression and reflection of the personality of the author, hence the adage 'style is man', by particularly generative stylisticians and the intentionalists" (Ghazala 2011: 40). Laying more emphasis on the linguistic approach of style, Abrams (1993: 203; emphasis his) defines style as "the manner of linguistic expression in prose or verse - it is how speakers or writers say whatever it is that they say". Based on these different schools of thought in defining style, Ghazala (2011: 41) defines style as a linguistic choice made by a particular author within the resources and limitations of language/ grammar, i.e. within "the total options available in the syntactic, semantic, phonological and pragmatic systems". In a direct link to translation, Nida and Taber (1969) in their definition of style touch on the patterning of choices as well as the generic constraints that play crucial roles in determining the author's style. However, style in this study is seen as any deviation that occurs within any language system (phonetics, graphology, semantics, grammar (morphology and syntax) and pragmatics), thereby creating marked and unexpected combination of sounds, graphics of writing, meanings, patterns of structures and so on. Such deviation does not happen randomly, but rather is driven by a deliberate and conscious selection made by the original writer. The concept of style indicates that in order to express their own ideas, feelings, attitudes, etc. authors try to choose among the available resources, thus using certain linguistic resources in preference to others (cf. McEnery \& Wilson 2001; Murphy 2006). This view accords well with the definition of style provided by Crystal (1989: 66; emphasis his):

Style is seen as the (conscious or unconscious) selection of a set of linguistic features from all the possibilities in a language. The effects these features convey can be understood only by intuitively sensing the choices that have been made [...] and it is usually enough simply to respond to the effect in this way. 
This entails that stylistic features are linguistic features in the first place, but characterized by markedness and significance. Therefore, such features place extra burden on the part of translators and require them to use their utmost effort to reflect such stylistic peculiarities in the target text (TT) (cf. Boarse-Berse 2006; Ghazala 2011; Huang 2011; Almanna 2013). However, difficulty arises when the target language ( $T L$ ) syntactic, semantic, phonological and pragmatic system rejects the accommodation of such features. Reading the text at hand with a view to analyzing and appreciating its salient stylistic features, such as parallelism, repetition, irony, long vs. short sentences, foregrounding vs. backgrounding, formality vs. informality, nominalisation vs. verbalisation, passivisation vs. activisation and so on, the translator's work automatically slows down in an attempt to adopt the most appropriate local strategies that would reflect such characteristics in the TT. In other words, in addition to the translator trying to reflect the content of the ST, another type of pressure is imposed on him/ her when attempting to relay stylistic peculiarities in the translation product.

Having formed a clear picture on what style exactly means, now let us shift our focus of attention towards the other concept, i.e. stylistics. In its straightforward meaning, stylistics is the study of style. Having consulted and discussed a number of definitions of stylistics (for example Widdowson 1975; Leech and Short 1981; Carter 1982; Brumfit and Carter 1986; Fabb et al 1987; Short 1988; Toolan 1992, 1998; Verdonk and Webber 1995; Wright and Hope 1996; Harris 2000; Simpson 2004; Boase-Beier 2006; Ghazala 2011; Yeibo 2011; Makokha, et al. 2012), one can conclude the following points about stylistics:

$>$ It is a branch of linguistics;

$>$ It is a language-based approach;

$>$ Its major concentration is on the analysis of literary texts of all genres and classes, whether canonical or non-canonical; however, it is an approach that can be applied to the analysis of other text types;

$>$ It is a combination of linguistic/structural patterns (i.e. stylistic features) and the implied meanings (or functions) produced by them;
It involves all types of stylistic choices at the different levels of language: lexical, grammatical and phonological, in particular.

\section{A stylistic approach to translating}

In this study, stylistics is envisaged as an approach which enables us to (1) analyze and describe varieties of language (linguistic stylistics), (2) identify and discern all important aesthetical aspects of text in order to interpret and appreciate texts properly (literary stylistics), (3) activate processes and experiences of reading along with our intuitive responses to the text at hand (affective stylistics), and (4) activate the knowledge stored in our mind on all aspects of language, text-typological demands, generic conventions, sociological roles of participants in the real world and in text, cultural environment and so on (cognitive stylistics). Therefore, it is a combination of four stylistic approaches, namely linguistic stylistics, literary stylistics, affective stylistics and cognitive stylistics. These four stylistic approaches do not exclude one another, but rather they complement one another. This is because text analysts (in our case translators) heavily rely on (1) their analytical and evaluative competence as well as their reading experiences and processes in order to identify the linguistic features that have acquired special status in the text and relate these linguistic peculiarities to their artistic function by analyzing their micro-and macro-context, and (2) on their intuitive response to the text by activating their knowledge on all aspects of language and human life. This indicates that although stylistics as an approach draws evidence from the text to support the argument for important stylistic features and their functions, it loses some of its appeal and becomes rather subjective due to its inherent nature. The reason is that people (be they readers, analysts, translators, or critics) are different in terms of their set of skills and competences, their socio-cultural backgrounds, their political and cultural commitments, their accumulated value system, the kind of information stored in their minds, their intuitive response and literary appreciation, and so on.

By adopting a style-based approach that can draw 
on the four stylistic approaches discussed above, translators, as special text readers, can easily derive a better understanding and appreciation of texts. Stylistics not only attempts to understand the linguistic foundations of the style in texts, in terms of the manner of expression, technique or craft of writing, but also lays emphasis on the language function of texts, in particular literary texts (cf. Toolan 1998: ix; Huang 2011: 59). Stylistics, therefore, seriously tries to "put the discussion of textual effects and techniques on a public, shared footing a footing as shared and established and inspectable as is available to informed language-users" (Toolan, 1998: ix). It provides us with a linguistic perspective to comprehend and appreciate the linguistic features that the original writers deliberately and consciously try to resort to, despite the availability of the other alternative options. This attunes well with BoaseBeier's (2006: 1) view:

Firstly, in the actual process of translation, the way the style of the source text is viewed will affect the translator's reading of the text. Secondly, because the recreative process in the target text will also be influenced by the sorts of choices the translator makes, and style is the outcome of choice (as opposed to those aspects of language which are not open to option), the translator's own style will become part of the target text. And, thirdly, the sense of what style is will affect not only what the translator does but how the critic of translation interprets what the translator has done.

\section{Discussion of data}

Todemonstratehowtranslators, asspecialtextreaders, can have a better understanding and appreciation of texts by adopting a style-based approach that can draw on the four stylistic approaches, i.e. linguistic stylistics, literary stylistics, affective stylistics and cognitive stylistics, let us discuss these two examples extracted from Yāsīn's story بصمة مو اطن A Citizen's Fingerprint (printed in Almanna 2013: 161): (Arabic examples are immediately followed by rough English literal translation in square brackets, which reflects their propositional content)

$$
\begin{aligned}
& \text { (1) أيـن المـلاذ؟؟ يريــــأن يفتح جناحيـه و يهـرب مـن ظمئسه }
\end{aligned}
$$

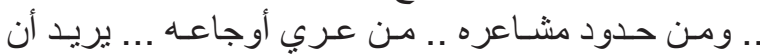

$$
\begin{aligned}
& \text { يحلق حيث لا أحد ... لا أحد أبـا. مئري. }
\end{aligned}
$$

[Where (is) the refuge? He wants to open his (two) wings and flee from his thirst .. and from the boundaries of his feelings .. from the nudity of his pains ... He wants to soar where there (is) nobody ... nobody at all]

In this example, one can easily identify, interpret and appreciate a number of stylistic features, viz. an elliptical rhetorical questioniأين الملادlit. where

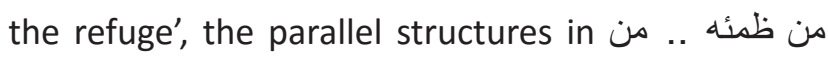
'lit. from his thirst .. from boundaries of his feelings .. from the nudity of his pains', the repetition of the lexical item يريد 'lit. (he) wants' and the repetition of the phrase لأحد 'lit. no one'. Here, these stylistic features are not used randomly by the original writer, but rather they are chosen deliberately and consciously; therefore, they are supposed to have particular functions. Resorting to a rhetorical question, for example, the original writer might attempt to get her readers physically involved in the situation or she might try to let them ponder over a particular refuge when being in a similar situation. Opting for lexical repetition in parallel structures, the writer might try to invoke in the mind of her readers different thoughts and images. Further, in an attempt to emphasize the fact that there will be nobody there at all, she resorts to a phrasal repetition حيث لا أحد 'lit. where (is) no one'. Given these stylistic features along with their functions full consideration, one can render it as follows:

(2) Where to go? He wants to spread his wings and escape from his thirst, from the boundaries of his feelings, from the nudity of his pains; he wants to soar where nobody is, nobody at all.

One should note that the suggested translation has preserved the stylistic features in the ST, viz. the elliptical rhetorical question, the parallel structures, the creative metaphors, and the functional repetition. The only modification has taken place in the lexis of the rhetorical question, that is, the option 
for synonymy (to go instead to seek refuge) and verbalizing the noun (to go instead of refuge) in order to preserve the elliptical structure as well as the tone. A rendering like 'Where is the refuge?' would sound flat in tone and as a generic rather than a rhetorical question, while renderings like 'Where can he find a refuge' or even 'Is there a refuge' would miss the abrupt ellipsis in the source language (SL) rhetorical question as well as mitigate the despairing tone in that question. Thus, the preservation of stylistic features can fluctuate between formal equivalence and functional equivalence. The first option, of course, is to maintain both form and function if that is possible at all. Otherwise, functional options become necessary.

In the following example, however, the original writer, in an attempt to invoke different images in the mind of the reader on the one hand, and to adopt a neutral tone on the other, opts for a circular pattern of an active and passive voice, which is supported by parallel structures as well as the deictic word هناك 'lit. there'.

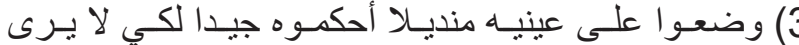

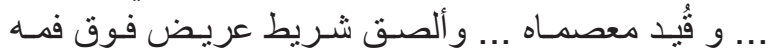

$$
\begin{aligned}
& \text {... ومضـو ا بـه إلى (هنـاك). }
\end{aligned}
$$

[They put a handkerchief on his (two) eyes(;) they tightened it well so he can't see ... His wrists were tied ... And a wide strip was stuck on his mouth ... And they took him (there)]

In addition to the parallel structures and the dynamic shift from active to agentless passive and back to active, the deictic Arabic word هناك 'lit. there' refers to an assumed location in the mind of the speaker/ writer, which is different from 'there' in the mind of hearer/reader as well as it invokes different memories and/or images. So, it is an open invitation to every reader in every location on the earth to enliven this moment of there-ness. Taken into account these stylistic features, one can readily produce a version that reflects the tone of voice and attitude, parallel structures and the deictic word 'there' at once, as in:
(4) They covered his eyes with a handkerchief, tightening it so that he couldn't see anything. His wrists were shackled; his mouth was covered with a wide piece of tape. And they took him 'there'.

Again, the only stylistic modification here has to do with textual preferences between Arabic and English. In this case, the English preference to use a non-finite clause 'tightening ...', rather than a finite clause 'they tightened ...', is the main reason for such a textual restructuring.

To demonstrate the impact of failing to, and/or succeeding in, reflecting certain stylistic features in authentic translation practice, let us consider the following example quoted from Greene's (1980: 9-10) The Bomb Party and translated into Arabic by Ali Sāalih (1989: 7-8):

(5) I think that I used to detest Doctor Fischer more than any other man I have known just as I loved his daughter more than any other woman.

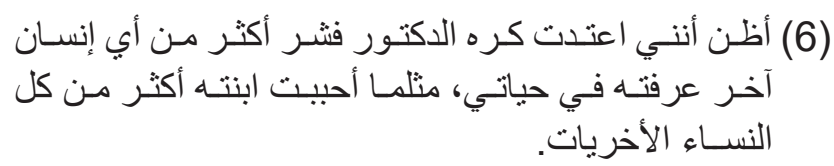

[I think I used to hate Dr Fischer more than any other human I have known in my life, as the way I loved his daughter more than all other women]

Here, it is apparent that the original writer uses parallelism: (I used to detest Doctor Fischer more than any other man/I loved his daughter more than any other woman). Such parallel structures need to be reflected in the TT, provided that such a reflection would not distort the TL linguistic and stylistic norms. Further, Greene, introduces two pairs of antonyms, i.e. 'detest' vs. 'love' and 'man' vs. 'woman' in a very short extract. As these antonyms fall in parallel structures, they acquire stylistic features that need to be maintained in the TT. Given these stylistic features full consideration, the translator could have produced a rendering as in (7) below: 


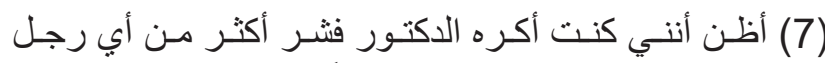

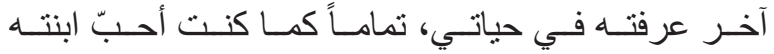

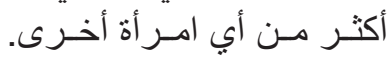

[I think I used to hate Dr Fischer more than any other man I have known in my life, just as I used to love his daughter more than any other woman]

Here, an attempt is also made to deliberately use antonyms in our suggested rendering: أكره vs. أحبّ 'lit. hate vs. love' and رجل امر أه أه أو 'lit man vs. woman'. It is also worth noting that the main reason for opting for the lexical item كره 'i.e. hate', rather than بغض i.e. hate + hostility' or مقت 'i.e. hate + censure' is to make up for the alliteration utilized by the original writer, i.e. detest Doctor. Besides, the suggested translation captures the lexical stylistic feature relaying emphasis in the SL, viz. the combination of just as lit. تماما كما rather than as Solone, by rendering it into the Arabic combination تماماً كما 'just as', which accounts for the said stylistic feature.

Let us now consider the following example where the translator has not preserved the cleft structure, which brings one constituent to marked focus and marked tone of discourse:

(8) But it was not for his money that I detested Doctor Fischer. I hated him for his pride, his contempt of the world, and his cruelty. He loved no one, not even his daughter. He didn't even bother to oppose our marriage, ...

$$
\begin{aligned}
& \text { (9) لكنتـي لـم أبغض الدكتور فشـر بسـبب أموالـه بـل بسـبب }
\end{aligned}
$$

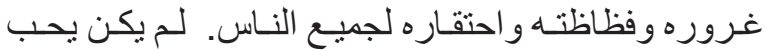

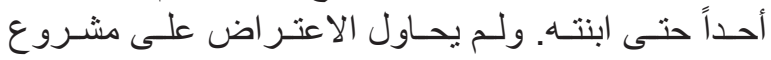

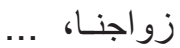

[But I didn't detest Doctor Fischer because of his money rather (it as) because of his pride and his cruelty and his contempt of all people. He didn't love anyone, even his daughter. And he didn't try to oppose the project of our marriage]

In this excerpt, the original writer, in an attempt to lay emphasis on the feeling of hatred that the narrator has towards Doctor Fischer, resorts to a cleft-structure in the negative form. Such an emphasis is however completely lost in the nexus of translation. Had the translator taken into account such a feature, he could لكن ثر اء الدكتور فشر have suggested a rendering such as

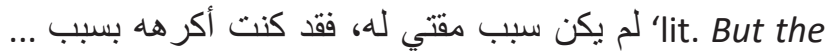
(huge) wealth of Doctor Fischer was not the reason for my detesting him, (in fact) I was hating (hated) him because ...'. Further, although the translator has managed to deal with the thematic progression in 'he loved .... He didn't ...' when opting for لم يكن ... ولم يحاول ' ل 'lit. he wasn't ... and he didn't try', he has changed the meaning of 'He didn't even bother to oppose our marriage' dramatically when lingering himself within the bounds of the superficial level of the sentence, thereby producing a neutral, flat rendering الم يحاول lit. He didn't try to oppose the project of our marriage'. Taken into consideration the thematic progression and probing into the deep symbolic level of the discourse, he could have

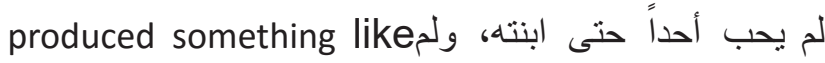
'lit. He didn't love anyone, (not) even his daughter, and he didn't try to (bother to) oppose even our decision to get married'. This translation captures the repetition of 'even' in the SL. Besides, the translator's option for two short sentences goes against the stylistic preferences in Arabic, hence combining the two short sentences into one in the suggested translation.

To witness translators' successes and failures while prioritizing the competing elements prior to finalizing their drafts, let us consider the following example quoted from Hemingway's novella The Old Man and the Sea (1952: 10) and translated by Munīr Ba'albaki (1985: 31), which involves several stylistic issues:

(10) They picked up the gear from the boat. The old man carried the mast on his shoulder and the boy carried the wooden box with the coiled, hard-braided brown lines, the gaff and the harpoon with its shaft.

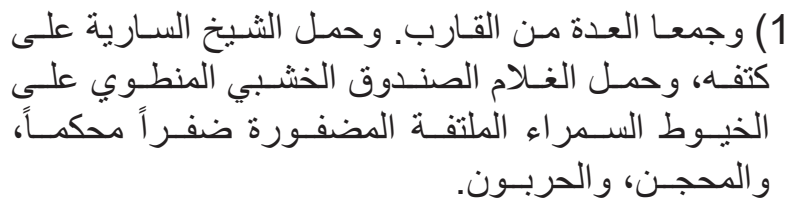


[And they gathered the equipment from the boat. The sheikh carried mast on his shoulder, and the (servant) youth/guy carried the wooden box (which was) coiled on the tightly-braided dark lines, and the gaff, and the harpoon]

First, this example involves lexical repetition which needs special attention. The lexical item 'to carry' is used in juxtaposed parallel structures and joined by the connector 'and': 'The man carried the ... and the boy carried the ...', thereby acquiring a stylistic feature that needs to be reflected in the TT, provided that this does not distort the TL linguistic and stylistic norms. Paying attention to these stylistic features at the syntactic level, the translator has managed to reflect them in the TT. However, he has seriously failed in handling the stylistic features at the lexical level. First, the English word 'boy' may potentially be translated into Arabic by a number of items, such as صبي ,ولد, غام etc. This requires translators to do their best to analyze and comprehend their both denotative and connotative meanings prior to rendering it. To start with, the English lexical item 'boy' and the Arabic word غلام proposed by the translator are different in their both denotative meanings (i.e. one of the sense components of the lexical item غلام is [+ adult] while the lexical item 'boy' is [- adult]) and connotative meanings (i.e. the Arabic word غلام invokes in the mind of the TL reader the idea of 'servitude'). As for ولد, its semantic features overlap with a 'male adult' (in Saudi Arabia, for example, a man is called and 'femaleness' in its plural form (i.e. the plural covers both 'boys' and 'girls'). From a stylistic point of view, translating the English lexical item 'boy' into صبي will create a sort of alliteration ( ... in the TT, which would enhance the TT while preserving its denotative and connotative features. Second, the translator has employed an unacceptable Arabic colour collocation, viz. الخيوط السمر اء, thus personifying and/or euphemizing a noun inadvertently and awkwardly. One should note that the Arabic color adjective أسمر/سمر اء is mainly used denotatively (i.e. to refer to an olive complexion) or euphemistically (i.e. to refer to a black complexion). There is no stylistic reason that would motivate its use to modify الخيوط, as the English open collocation 'brown lines' can be readily rendered into الخيوط البنّية الخيو,, thus avoiding unmotivated stylistic nuances.

By contrast, to see how a translator can successfully handle the main stylistic features of lexis and structure in the ST, let us consider the example below quoted from Abid's (2010) story the Passion of Lady A and translated by Erick Winkel (2010).

(12) لـم يكن بريد التفكير بشـيء محدد، فقد سـحره المشـهـ

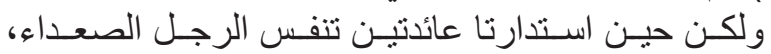

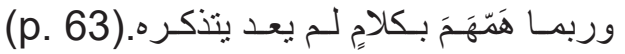

[He wasn't wanting (didn't want) to think of any specific thing, as the scene intoxicated him and but when they turned going back the man heaped a sigh of relief, and perhaps he mumbled some speech he no longer recalled]

(13) He didn't want to think of anything in particular. The vision had intoxicated him. But when they turned around to go back, the man sighed deeply. He may have mumbled some words he couldn't recall later. (p. 62)

Here, the translator has effectively managed to relay a comparable degree of emotiveness in the translation by employing the appropriate lexical chain 'intoxicated ... sighed deeply ...mumbled'. In addition, he has ably split the Arabic sentence into three English sentences, thus complying with the stylistic norms in the TT. The only small stylistic mishap one could notice is the translator's use of the active rather the passive voice with a verb like 'intoxicate' as English tends to utilize the passive with this verb and other similar verbs like 'enchant' and 'captivate', which might well be employed in this context.

However, the same translator has failed to capture some stylistic features in the following excerpt:

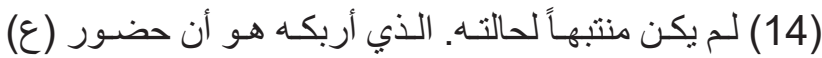

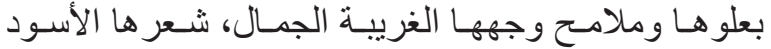

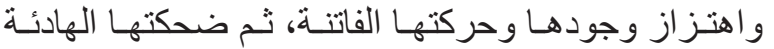

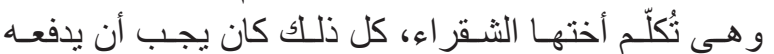

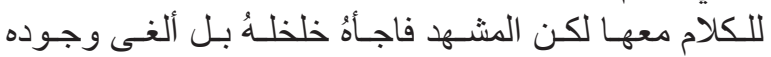
وجعله لا شـيء تقريبـاً .. (p.65) 
[He didn't pay attention to his condition. What confused him was the presence of Lady A with her height and her face's features (which are) extraordinarily beautiful, her black hair and her shaking presence and her seductive movement, then her calm laugh while talking to her blonde sister, all that would have pushed him to talk to her but the scene took him by surprise(,) disjointed him(;) rather it cancelled his existence and made him almost nothing]

(15) He wasn't aware of his condition. What muddled him was the lady's height, good looks, attractive face, and beauty, her enticing presence and seductive walk. Then she laughed quietly while chatting with her fair sister. All of that would have pushed a man to talk with her, but seeing her suddenly disjointed him, shook off his being and made him almost disappear. (p. 64)

As can be seen, the translator has changed the relationship between the first sentence and the following one dramatically when opting for the connector 'then' in 'What muddled him was the lady's height, good looks, attractive face and beauty, her enticing presence and seductive walk. Then she laughed quietly while chatting with her fair sister'. First, the action of laughing was excluded from what muddled him, and second, the sequence of the events was changed. He could have used the connector 'as well as' as in 'as well as her quiet laughter while she was chatting with her blonde sister'. From a stylistic viewpoint, there is an example of climax, i.e. arranging words, phrases, clauses according to their increasing importance (cf. Corbett 1971: 476; Al-Rubai'i 1996: 86). Such a stylistic feature needs to be given full consideration by the translator, but unfortunately he has paid no attention to the arrangement of the clauses/sentences in an order of increasing importance. Further, climax is accompanied by a deliberate omission of some of the connectors, i.e. فاجأه خلخله بل ألغى وجوده وجعله لا شيء ثقريبا 'lit. took him by surprise disjointed him rather cancelled his existence and made him almost nothing', as well as a lack of punctuation marks among these clauses/ sentences. The omission of punctuation marks is on purpose; it is one of the rhetorical devices employed by the writer to "hasten psychologically the pace of the experience depicted" (Shen 1987: 186). Had the translator taken such stylistic features into account, he could have produced a rendering such as 'But the sight surprised him ... rocked him ... rather obliterated his existence and made him almost nothing'.

To further demonstrate how not taking into account the deliberate and conscious selections made by the original writer may create a misleading mental image in the minds of the TL readers, let us consider the following excerpt (16) quoted from Choukri's novel (2000: 171-172; 6 6 edition) and translated by Bowles into For Bread Alone (2000: 128):

$$
\begin{aligned}
& \text { انسحب النادل وقال لي: }
\end{aligned}
$$

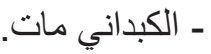

$$
\begin{aligned}
& \text { ـ قلت بصوت ضعيف، فاتحاً عيني، فاغر اً فمي: } \\
& \text { - } \\
& \text { - نعم مات. رحمة الله عليه. }
\end{aligned}
$$

[The waiter retreated and said to me:

- Kebdani died.

I said in a weak vice, opening my eyes, pushing my mouth open:

- Died?

- Yes died. Allah's mercy on him]

(17) After he had gone away, Kandoussi resumed talking.

"Poor Kebdani. He's dead".

My eyes and mouth opened widely. "Dead" I repeated weakly.

"Yes", he said. "He's dead. Allah irhamou.

Drawing a direct comparison between the ST and TT, one can easily put a finger on the translator's failure to interpret and appreciate the original stylistic features, such as the repetition of the Arabic verb مات 'died', which is unjustifiably changed into adjective in the TT, i.e. 'dead', along with its function in such a dialogue. Changing parts of speech through the nexus of translation, which is labeled by Vinay and 
Darbelnet (1958/1995) 'transposition' and later by Catford (1965) 'class shift', needs to be avoided as much as possible, in particular when it leads to a different mental image on the one hand, and alters the text-type focus on the other. Besides, the effect of suddenness in the parallel structure فاتحاً عيني، is best relayed in English by inchoative finite clauses, viz. 'My eyes opened, my mouth gapped. - He died? I repeated weakly'. More seriously, however, the translator has resorted to transliteration in his rendition of the formulaic expression رحمة الله عليه. This decision has marred the style of the English text. The translator could have chosen between foreignization, viz. 'May Allah have mercy on him' or domestication, viz. 'May his soul rest in peace'. Both options would fit nicely in the TT, albeit they embrace different styles.

Sometimes, the translator opts for a style that is not congruent with the style of the original author. For example, in his translation of Hemingway's The Old Man and the Sea, Munīr Ba'albaki has chosen an elevated style that does not reflect the simple narrative style adopted by the author. One could sense this outright from the translation of the title into النيخ و البحر 'lit. The Sheikh and the Sea', rather than the straightforward title الرجل العجوز و البحر 'lit. The Old Man and the Sea'. It is worth noting that the Arabic term الثيخ 'sheikh' brings to mind many connotations in the Arab culture including religious, political, social, educational, and old age connotations. Among these, it is only the old age connotation that is relevant to Hemingway's work. To shed more light on the difference in style, let us consider the following excerpt, along with its Arabic translation:

(18) He [the fish] took the bait like a male and he pulls like a male and his fight has no panic in it. I wonder if he has any plans or if he is just as desperate as I am?

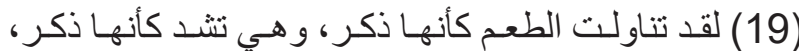

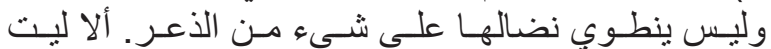

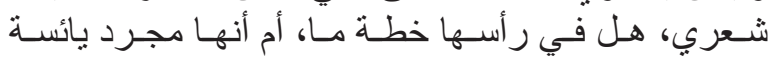
متلبي أنـا؟ هـ
[She took the bait as if she were a male, and she was pulling as if she were a male, and her struggle doesn't contain any panic. Where's my verse (who knows), is there a certain plan in her head, or is she merely desperate as I am?]

Apart from the modification of the fish's gender (from male to female, which has been adopted throughout the translation of the novella), Munīr Ba'albaki has employed two highly elevated expressions here, viz. ألا ليت شعري and الضالها, which are not congruent with the simple narrative style in the ST. The first expression is highly formal corresponding to "her struggle' in English, which does not describe the situation at hand; it could simply be rendered as sعركتها 'her fight'. The second expression is more problematic as it is taken from Arabic classical poetry (wondering by invoking one's own verse), which does not reflect the ST simple style that can be simply

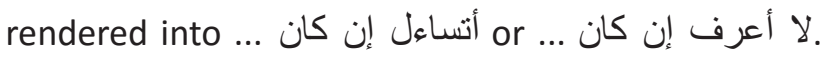
In fact, the Arab reader of Ba'albaki's translation gets a wrong impression of Hemingway's style. The two styles are completely different: the translation's style is highly elevated and largely stilted, whereas the original's style is that of a simple narrative and is highly readable.

The following example, taken from Victims of a Map - a group of selected poems by M. Darwish, S. AlQasim, and A. Adonis, and translated by Abdullah Al-Udhari (1984), demonstrates how making small changes, perhaps inadvertently, can seriously affect poetic symbols, which are a key feature of style. The excerpt comes from Darwish's poem II I Were to Start All Over Again':

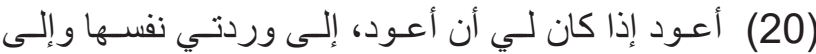

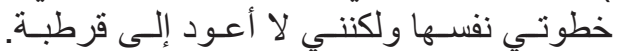

[I return if I were to return, to my rose itself and to my step itself (and) but I don't return to Cordova]

(21) I will return if I have to return, to my roses, to my steps But I will never go back to Cordova.

In (21), the translator has failed to deal with the 
symbolic representation in two serious ways. Firstly, he has destroyed the symbolism embodied in the uniqueness of the referents which the poet employs, that is, وردني 'my rose' and خطوني 'my step' when rendering them as 'my roses' and 'my steps', respectively. One should note that the poet utilizes these common nouns in reference to unique entities, viz. 'my rose' symbolizes 'Palestine (his occupied homeland)' and 'my step' symbolizes 'his infancy'. Unfortunately, the translation relegates these poetic symbols to mere reference to common belongings. Secondly, the modality of the discourse presented by the translator is significantly different from that entertained by the poet. To explain, the translation views 'the return' in terms of general obligation 'if I have to return', thus calling into question the cherished desire to return to occupied land, whereas the poet envisions 'the return' as a remote possibility إذا كان لي أن أعود 'if / were to return' while maintaining this long-cherished desire. As is clear, we have two different styles which embrace considerably diverging discourses and worlds.

Let us now consider our last example of stylistic features in which ideological moves are presented at the level of poetic cohesiveness rather than sociocultural reality. The stanza below is extracted from a poem titled الطوفان و الشجرة 'The Flood and the Tree', which was written in the aftermath of the 1967 ArabIsraeli War by the Palestinian woman poet, Fadwa Tūqān, and was translated into English by Ibrahim Dawood (1994:44-45):

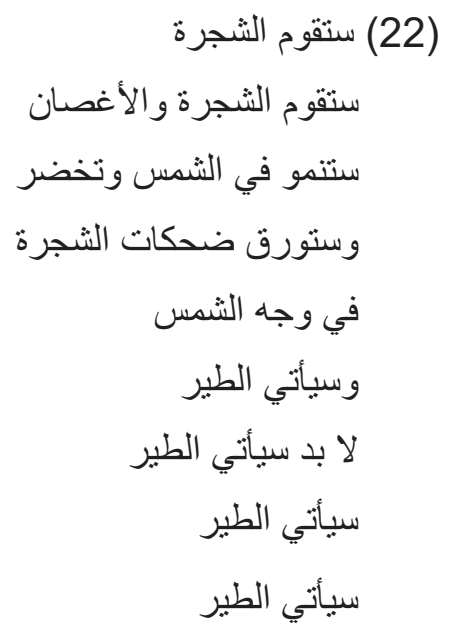

[The tree will rise

The tree and the branches will rise

(It) will grow in the sun and green

And the laughs of the tree will leaf in the face of the sun

And the bird will come

The bird must come

The bird will come

The bird will come]

(23) This fallen Tree will rise again with green branches in sunshine. Her smiles will be her leaves That will appear in the sunlight. The Bird will come; it will most surely. The Bird will come, the Bird will come.

It can be readily seen that the translation in (23) transforms an episode of inflamed agitation and fury by the poet into a state of deep serenity. Given the psychological turbulence the poet is experiencing after the tragic defeat of the Arabs in the 1967 Sixday War, she bombards the reader with a series of actions, viz. ستقوم 'will rise', ستنمو 'will grow', تخضر 'will green', ستورق 'will leaf', and سيأتي 'will come', where there is no room for serene states. However, the translation betrays this stylistic feature by disrupting it with states that involve minimal action, if any at all, viz. with green branches in sunshine, Her smiles will be her leaves, and that will appear in the sunlight. This, in effect, seriously damages poetic cohesion and coherence. To appreciate the importance of maintaining this stylistic feature, the following translation is offered as a mere suggestion:

(24) The Tree will rise again;

Her branches will grow and green in the sun;

Her smiles will leaf in sunshine;

The Bird, the Bird shall surely come;

The Bird will come, the Bird will come.

\section{Conclusion}

The discussion of the above examples along with their translations clearly shows the effects of the translator's appreciation of stylistic features on his/her work. The 
moment translators identify and appreciate stylistic features, they start pondering over the available strategies, on the one hand, and the amount of loss that may occur through the nexus of translation, on the other. To work smoothly and effectively through stylistic nuances, translators need first to develop an analytical and evaluating competence that enables them to analyze and appreciate stylistic features, and second to demonstrate a transfer competence that enables them to choose appropriately between the competing elements with a minimum loss. It has been shown that in order to be in a position to render literary texts effectively and accurately, translators need to:

i. analyze and describe varieties of language;

ii. identify and discern all important aesthetical aspects of text in order to correctly interpret and appreciate texts;

iii. activate processes and experiences of reading along with our intuitive responses to the text at hand; and

iv. activate all aspects of knowledge stored in their minds on language, text-typological demands, generic conventions, sociological roles of participants in the real world and in text, cultural environment and so on.

Further, it has been shown from data analysis that translators can have a better understanding and appreciation of texts, in particular literary texts, when adopting a style-based approach that can draw on the four stylistic approaches, viz. linguistic stylistics, literary stylistics, affective stylistics and cognitive stylistics. It has been also shown that stylistics as an approach draws evidence from the text to support arguments for the importance of stylistic features and their functions. However, it loses some of its appeal and becomes rather subjective as people are different as to their socio-cultural backgrounds, their political and cultural commitments, their ideologies, their skill competences, the kind of information stored in their minds, their intuitive responses and literary appreciation, and so on.

\section{References}

Abrams, M. (1993). A Glossary of Literary Terms. London: Harcourt Brace Jovanovich College Publishers.

Almanna, A. (2013). Quality in the Translation of Narrative Fictional Texts from Arabic into English for the Purposes of Publication: Towards a Systematic Approach to (Self-) assessing the Translation Process. Unpublished PhD dissertation. University of Durham. England.

Al-Rubai'i, A. (1996). Translation Criticism: A Model for Assessing the Translation of Narrative Fictional Texts. Unpublished PhD dissertation. University of Al-Mustansiriyah. Iraq.

Al-Udhari, A. (1984). Victims of a Map (bilingual edition). Saqi Books. London.

Ba'albaki, M. (Trans.) (1985). al-Shaykh wa al-Bahar. Beirut: Dār al-'ailm lil Malāyīn.

Boase-Beier, J. (2006). Stylistic Approaches to Translation. St. Jerome Publishing. Manchester, UK.

Bowles, P. (Trans.) (1993). For Bread Alone. Saqi Books. London.

Bragina, J. (2012). A cognitive stylistic analysis of J.R.R. Tolkien's fantasy world of Middle-earth. Unpublished PhD dissertation. University of Glasgow. UK.

Catford, J. C. (1965). A Linguistic Theory of Translation. Oxford University Press. Oxford.

Chokri, M. (2000). al-Khubiz al-hhafi. (6 $6^{\text {th }}$ edition). Saqi Books. London.

Corbett, E. P. (1971). Classical Rhetoric for Modern Student. Oxford University Press. Oxford.

Crystal, D. (1989). The Cambridge Encyclopedia of Language. Cambridge University Press. Cambridge.

Dawood, I. (Trans.) (1994). An English Translation of Selected Poems by Fadwa Touqan. Yarmouk University Press. Irbid.

Ghazala, H. (2011). Cognitive Stylistics and the Translator. Sayyab Books Ltd. London. 
Greene, G. (1980). The Bomb Party. Penguin Books. Harmondsworth.

Harris, R. (2000). Will stylistics ever grow up? Paper delivered at the $\mathrm{XX}$ International Poetics and Linguistics Association Conference at Goldsmiths College: London, on July $1^{\text {st }}$.

Hemingway, E. (1952). The Old Man and the Sea. Penguin Books. Harmondsworth.

Hough, G. (1969). Style and Stylistics. Routledge and Kegan Paul. London

Huang, X. (2011). Stylistic Approaches to Literary Translation: with Particular Reference to EnglishChinese and Chinese-English Translation, Unpublished PhD dissertation. University of Birmingham.UK.

Kussmaul, P. (1995). Training the Translator. John Benjamins. Amsterdam and Philadelphia.

Leech, G. and Short, M. (1981). Style in Fiction: A Linguistic Introduction to English Fictional Prose. Longman. London.

Makokha, J. K. S. Ogone, J. O. and West-Pavlov, R. (2012). Style in African Literature: Essays on Literary Stylistics and Narrative Styles - Internationale Forschungen zur Allgemeinen und Vergleichenden Literaturwissenschaft. Rodopi. Amsterdam and New York.

McEnery, T. and Wilson, A. (2001). Corpus Linguistics. Edinburgh University Press. Edinburgh.

Murphy, S. (2006). Now I am alone: A corpus stylistic approach to Shakespearian soliloquies. In C. Gabrielatos, R. Slessor and J. W. Unger (Eds.). Papers from the Lancaster University Postgraduate Conference in Linguistics \& Language Teaching, Vol. 1. (Papers from LAEL PG), pp. 66-85. University of Lancaster. Lancaster.

Nida, E. and Taber, C. R. (1969). The Theory and Practice of Translation. Brill. Leiden.

Sāilih, A. (trans.) (1989). Haflat al-Qunbulah. Dār alShū'ūn al-Thaqāfia al-'amah. Baghdad.
Shen, D. (1987). Literary Translation and Translation: with Particular Reference to English Translations of Chinese Prose Fiction. Unpublished PhD dissertation. University of Edinburgh. Edinburgh.

Snell-Hornby, M. (1995). Translation Studies: An Integrated Approach. John Benjamins. Amsterdam.

Toolan, M. (1998). Language in Literature. Hodder. London.

Vinay, J. P. and Darbelnet, J. (1958/1995). Stylistique comparée du français et de l'anglais. Méthode de traduction, Paris: Didier (Trans. and Ed.) J. C. Sager and M. J. Hamel 1995. Comparative Stylistics of French and English: A Methodology for Translation. John Benjamins. Amsterdam and Philadelphia.

Winkel, E. (Trans.) (2010). Nights of Mr Salman: a bilingual reader. Sayyab Books Ltd. London.

Yeibo, E. (2011). Patterns of Lexical Choices and Stylistic Function in J. P. Chlark-Beederemo's Poetry. In A. Ahmadi, (Ed.). International Journal of English Linguistics. Pp. 137-149. Canadian Center of Science and Education. Toronto.

Zyngier, S. (2001). Towards a Cultural Approach to Stylistics. CAUCE, Revista de Filología ysu Didáctica, Vol. 24, pp. 365-380. 